\title{
Effect of the Amabolic Agent Zeranol on Growth Performance, Testis Development and Adrenal Weight of Weaning Rabilts
}

\author{
M. Mohamed , and E. Ellorabbak \\ Dept. of Animal Prod., Fac. Agric., Kafr El-Sheikh., Tanta Univ., \\ Egypt.
}

\begin{abstract}
7 HE anabolic agent zeranol was used as subcutaneous implants for 1. weanling male rabbits in doses of a sirgle 1-mg-implant, two 1-mg-implars (36-day interva) or a single 2 -mg-implant. Effects of the drug on growth rate, efficiency of feed utilization, adrenal weight and morphological und histological testicular developurent over a is-welk-period were investigated.

No significant difference in magnitude of body weight gain, average duily gain or efficiency of feesl utilization could be detected between impiarted ans non-implanted rabbits. Neither repeating inrplantation on day 56 or doubling the dose could increase weight gain or improve efficiency of feed utilization.

Zeranul implants caused significant increase in adrenal weigth. Testis of Ztranol-implasted rabbits were murkodly atrophied, showing decrused weight, narower seminiferous tubules with less active germinal epithilium snd reduced number of sperm reserves when compared wiuh gonals of intact non-implanted rabbits.
\end{abstract}

Keywords: Rabbic, Zeranol, Growth performanse, Testis, and sárenal

Zeranol is a synthetic derivative of the mycotoxin zearalenone which is produced by a number of Fuzarizum species and is known to be a phytoestrogen (Mirocha et al., 1977). Although it has beer widely marked during the last decade as a growth promotant for catule shecp, recent research has revealed inconsistent results about its role as a growth stimulant. Many workers reported that implanting young balls with zeranol did not significantly affect body weight gain (Corah et al., 1979;Ford and Gregory, 1983; Juniewicz et al., 1985; Gray et al., 1986; Sìcox et al., 1986; Godfrey êt al., 1989). In contrast, some have found zeratrol to increase weight gain in bulls (Fabry et al., 1983; Greathous et al., 1983) while others have reported decreased growth performance due to zeranol implantation (Gray et al., 1984). 
Characterization of the effects of zeranol on male cattle and sheep was undertaken and involved the determination of testicular development and/or pituitary hormone secretion patterns. Generally, zeranol implants were found to inhibit testicular growth and suppress spermatogenesis and testosterone production if implanted during the preweaning growth period, while no significant effects were observed if animals were treated latter (Ralston, 1978; Elsasser et al., 1983; Juniewicz et al., 1985; Staigmiller et al., 1985; Gray et al., 1986; Silcox et al., 1986; Godfrey et al., 1989).

Almost no infomation is available about the response of male rabbit to this anabolic agent implants. Therefore, the current work was designed to evaluate the possibility of using zeranol as a growth promotant for increasing rabbit meat production and to investigate its effecis on testis function and adrenal development of weaning rabbits.

\section{Materival and Methods}

\section{Animals}

Forty-eight 5 to 6-week-old weanling New Zealand White male rabbits with an average body weight of $858+29.7 \mathrm{~g}(\overline{\mathrm{x}} \pm$ S.E. $)$ were taken at random from a flock at the Poultry Reseanch Farm of Kafr El-Sheikh Faculty of Agriculture, Tanta University, Egypt Animals were kept in metallic batteries ( 3 animals/cage) and fed ad libitum a pelleted diet containing $17.38 \%$ crude protein, $10.94 \%$ crude fiber, $2.58 \%$ ether extract and $4.19 \mathrm{Kcal} / \mathrm{g}$ gross energy on dry matter basis.

\section{Growts implant}

The anabolic agent zeranol (Ralgro, International Minerals and Chemicals Corporation, Terre Haute, In, USA) was used as subcutaneous implants in the dorsal part of the neck just behind the head.

\section{Experimental design}

Animals were randomly divided into four groups $(A, B, C$ and $D)$ of 12 rabbits each ( 4 cagges i.e. 4 replicates). The different groups were assigned to serve as controls or to receive implants of zeranol as follows;

Group A: served as control nontreated.

Group B: received a single l-mg-implant of zeranol on day 0 .

Group $C$ : receied two l-mg-implants of zeranol, one on day 0 and the other eight weeks latter (on day 56).

Group D: received a single 2-mg-implant of zeranol on day 0. 


\section{Characteristics studied}

Growth rate and efficiency of feed utilization

In dividual weights and amount of diet fed to each cage ( 3 animals) were obtained on day $28,56,84$ and 112 postimplatation for growth rate and feed/gain ratio calculations.

\section{Morphological and histological studies}

Three animals with the average body weight in each group were chosen on days 56 and 112 for studying the influence of the growth implant on testicular and adrenal development. Animals were sacrificed then testes and adrenals immediately removed and weighed. The testis of the right side was fixed in $10 \%$ buffered formalin, dehydrated in a series of graded alcohol, embedded in paraffin, sectioned serially at 7 microns, mounted and stained with hematoxylin and eosin for histological evaluation at light microscope level. Seminerferous tubule diameters were determined on 100 tubules/rabbit of different size and shape. The widest and narrowest diameter of each tubule was measured and the average was calculated. Differentiation of germ cells in the various stages of the seminiferous epithelial cycle was also noted. Tunica albuginea of the left testis was carefully removed and weighed, while the parenchyma was processed according to the method described by Orgebin-Crist (1968) for the determination of testicular sperm reserve.

\section{Statistical analysis}

All data obtained were statistically analyzed for differences due to treatment by least squares analysis of variance (Snedecor and Cochran, 1976).

\section{Results and Discussion}

Effect of zeranol on growth and efficiency of feed utilization is shown in Table 1. No significant difference in magnitude of body weight gain or average daily gain over the 16-weeks experimental period between implanted and nonimplanted weanling rabbits could be detected $(\mathbb{P}<0.05)$.

Similarly, zeranol did not alter feed consumption or efficiency of feed utilization. Neither repeating implantation on day 56 (group C) nor doubling the dose implanted (group D) could increase weight gain or improved efficiency of feed utilization. These results are in consistent with previous reports on bulls (Baker and Arthaud, 1972; Corah et al., 1979; Ford and Gregory, 1983; Staigmiller et al., 1985; Juniewicz et al., 1985; Gray et al., 1986; Silcox et al., 1986) and rams (Wiggins, 1976). However our results are in contrast with many others who claimed that zeranol increased the growth rate of both growing and fattening animals (Perry et al, 1970; Thomas and Armitage, 1970; Thomas et al., 1970; Staigmiller et al., 1983). 


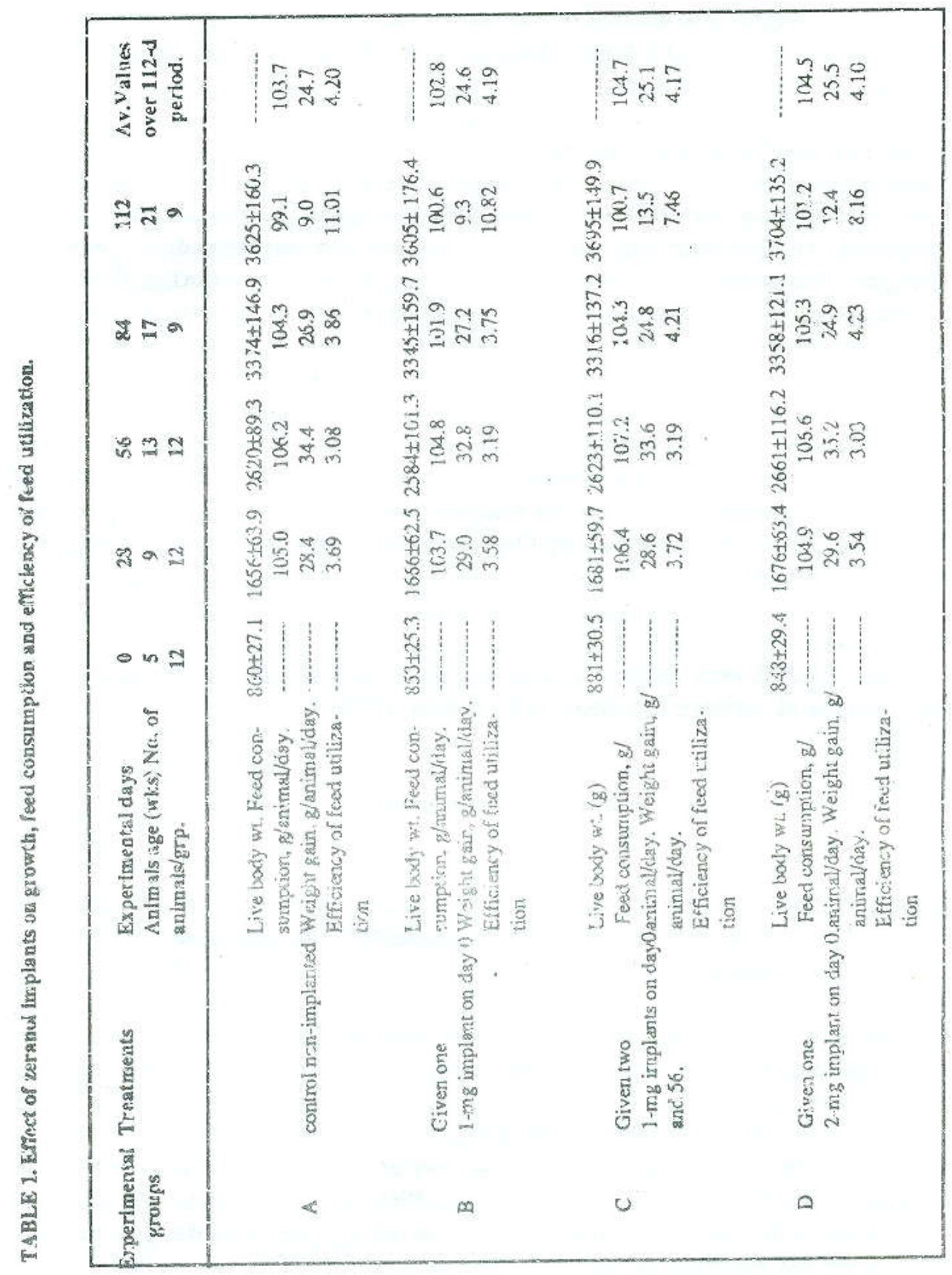

Egypt. J . Anim. Prod ., 28, No.1 (199?) 
Resuits conceming the effect of zeranol on adrenal and testis development are presented in Table 2. Adreskl weight was markedly affected by zeranol implants. Intact (non-implanted) rabbits had significantly lighter adnenal glands than zeranol-implanted ones on day 56 and 112 after implantation $(P<0.05)$. No significant differences among the three treated group $(B, C$ and $D)$ could be detcted $(P>0.05)$. These results confirm those reported by Rorger et al. (1973) on steers and Wiggins et al. (1976) on lambs. The larger adrenal glands of implanted rabbits may reflect androgen production by the steroidogenic cells of the adrenal cortex. It is possible that zeranol through its estrong-like effect may increase adrenal cortical steroids production, either due to direct. action of estrogen on the adrenal cortex or through increased ACTH release.

Testicular deveiopment was drastically influenced by zeranol implants. After 56 days of implantation paired vestis weight for control animals was about $187.2 \%, 182.0 \%$ and $185.5 \%$ of that for treated grousp $B, C$ and $D$ respectively. On day 112 the corresponding values were $182.6 \%, 189.8 \%$ and $162.9 \%$ consequendly. Besides, weight of tunica aibuginea as percentage of testis weight in implanted animals was significandly grcater that that in controls $(P<0.05)$. Statistical analysis could not reveal any significant differences among the throe treatsents which may indicate that the single 1-mg-implant was sufficient enough to cause the adverse effects obscrved.

Under histological examination gonds of zeranol inplanted rabbits appeared to have much less active germinal epithelium than intact animals. Sections in samples taken after 56 days of implantaion (anirnals age about 13 wks.) are shown in Fig.1. T'estis of intact males showed apperently larger seminiferous tubules compared with those of treatod animals. All tubules had spermatogonia and primary spermatocytes. Some primary spermatocytes were undergoing meiotic division to form the secondary spermatocytes which were present in some tubules (Fig. 1, A). Sections of zeranol-implanted males showed significantly narrower tubules $(P<0.05)$ with less number of spermatogonia and few number of primary spermatocytes. Nuclei of syermatogonia and Lyding cells appeared pylnotic (Fig. 1; B, C and D).

By the day 112. after implartation (animals age about 21 wks.) testis sections of intact males showed the typical apperance of full active gronads. All stages of spermatogenesis were present. Fernarkable lumen in the middle of each tubule was noticed with bundles of spermatczoa around (Fig. 2, A). The average diameter of seminiferous tubules in this gurup was nearly $166 \%$ of that in treated groups. Testis sections of zerancl-implanud rabbits were characterized by less diameter of seminiferous tubules and the absence of spenatozoa bundles found in case of intact animals. Spermatogenesis developed up wo the formation of spermatids. Metamorphism of spermatids to form spermatozon have not begun yet (Fig. 2; B,C and D). This indicates that gonads of these animals were still unable so produce mature spermatozoa.

Egypt. J. Arims. Prod ., 28, No.1 (1991) 
TABLE 2. Wffect of zeranol iwplank on adremal weight, testis weight, alameter of

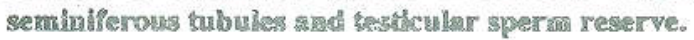

\begin{tabular}{|c|c|c|c|c|}
\hline $\begin{array}{c}\text { Experimental grousp } \\
\text { trentment }\end{array}$ & $\begin{array}{c}\text { A } \\
\text { Controd } \\
\text { nom-inoplsanted }\end{array}$ & $\begin{array}{c}\text { D } \\
\text { Given owe 1-my } \\
\text { lmylast on day } \\
\text { f. }\end{array}$ & $\begin{array}{l}\text { C } \\
\text { Given swo l-mg } \\
\text { implart s on day } \\
\text { fiad } 5 \% \text {. }\end{array}$ & $\begin{array}{c}\text { Given ane 2-ind } \\
\text { implant on day } \\
0 .\end{array}$ \\
\hline \multicolumn{5}{|c|}{$1-0 \mathrm{day} 56$} \\
\hline $\begin{array}{l}\text { Body weight (g) } \\
\text { Adrenal weight, (mg) }\end{array}$ & $\begin{array}{l}2610.0 \pm 10.29 \\
348.0 \pm 19.836\end{array}$ & $\begin{array}{l}2590.0 \pm 11.47 \\
476.0 \pm 20.08 \mathrm{a}\end{array}$ & $\begin{array}{l}2631.0 \pm 12.63 \\
452.0 \pm 16.66 \mathrm{a}\end{array}$ & $\begin{array}{r}2615.0 \pm 9.96 \\
503.0 \pm 21.11 \mathrm{z}\end{array}$ \\
\hline Paired testis weigh, (mg) & $1848.0 \pm 86.43 \mathrm{~g}$ & $987.0 \pm 51.453$ & $1015.0 \pm 73.82 \mathrm{~b}$ & $996.0 \pm 62.73 i$ \\
\hline $\begin{array}{l}\text { Weight of tunica albugines } \\
\text { of the left testis, (mg) } \\
\text { (as\% of testis wt.) }\end{array}$ & $\begin{array}{l}132.0 \pm 11.14 \\
13.2 \pm 1.13 b\end{array}$ & $\begin{array}{l}146.0 \pm 10.88 \\
29.2 \pm 2.21\end{array}$ & $\begin{array}{r}169.6 \pm 12.33 \\
32.2 \pm 2.98 \mathrm{a}\end{array}$ & $\begin{array}{r}164.0 \pm 11.67 \\
30.6 \pm 2.87 \mathrm{a}\end{array}$ \\
\hline $\begin{array}{l}\text { Diameter of semineferour } \\
\text { tubules, (microns) }\end{array}$ & $\begin{array}{c}79.6 \pm 6.35 \text {. } \\
0\end{array}$ & $\begin{array}{c}47.4 \pm 7.11 b \\
0\end{array}$ & $\begin{array}{c}41.9 \pm 6.85 b \\
0\end{array}$ & $\begin{array}{c}39.9 \pm 5.82 b \\
\mathrm{c}\end{array}$ \\
\hline \multicolumn{5}{|c|}{$\mathrm{II}=\mathrm{Or}$ day 112} \\
\hline Body weight (g) & $3632.0 \pm 18.73$ & $3608.0 \pm 19.91$ & $3652.0 \pm 12.56$ & $3590.0 \pm 18.73$ \\
\hline Adrenal weight, (mg) & $357.0 \pm 12.95 b$ & $439.0+21.70 \mathrm{z}$ & $471.0 \pm 20.85 a$ & $428.0 \pm 19.77$ \\
\hline Paired testis weigh, (mg) & $2938 \pm 93.09 \mathrm{~s}$ & $1618.0 \pm 85.150$ & $1548.0 \pm 77.231 \mathrm{~b}$ & $1804.0 \div \pm 71.11 \mathrm{~b}$ \\
\hline $\begin{array}{l}\text { Weight of tunica albugine: } \\
\text { of the left testis, (mg) (as\% } \\
\text { of testis wt.) }\end{array}$ & $\begin{array}{l}88.0 \pm 9.15 b \\
5.4 \pm 0.68 b\end{array}$ & $\begin{array}{c}117.0 \pm 8.81 \mathrm{ab} \\
12.8 \pm 1.11 \mathrm{~s}\end{array}$ & $\begin{aligned} 134.0 & \pm 7.25 a \\
16.3 & \pm 1.42 \mathrm{a}\end{aligned}$ & $\begin{array}{r}115.0 \pm 8.86 \mathrm{ab} \\
12.1 \pm 1.03 \mathrm{a}\end{array}$ \\
\hline $\begin{array}{l}\text { Diameter of semineferouss } \\
\text { tubules, (microms) }\end{array}$ & $163.9 \pm 13.43 \mathrm{~s}$ & $98.8 \pm 10.44 b$ & $93.9 \pm 8.79 b$ & $96.7 \pm 9.99 b$ \\
\hline $\begin{array}{l}\text { Testicular sperm reserve for } \\
\text { the left testis X } 10^{6} \text {, } \\
\text { (wotal) (/g tissue) }\end{array}$ & $\begin{array}{l}284.2 \pm 19.99 \mathrm{a} \\
173.5 \pm 13.52 \mathrm{a}\end{array}$ & $\begin{array}{l}45.5 \pm 6.36 b \\
49.5 \pm A .73 b\end{array}$ & $\begin{array}{l}39.8 \pm 4.67 b \\
48.2 \pm 4.59 b\end{array}$ & $\begin{array}{l}43.5 \pm 8.44 \mathrm{~b} \\
45.8 \pm 4.39 \mathrm{~b}\end{array}$ \\
\hline
\end{tabular}

$\mathrm{a}, \mathrm{b}, \mathrm{c}$, Means in the same row that do not have a cormmon superscript letter are significantiy different at PS0.05.

Egypt. J. Anim. Prod ., 28, No.1 (1991) 


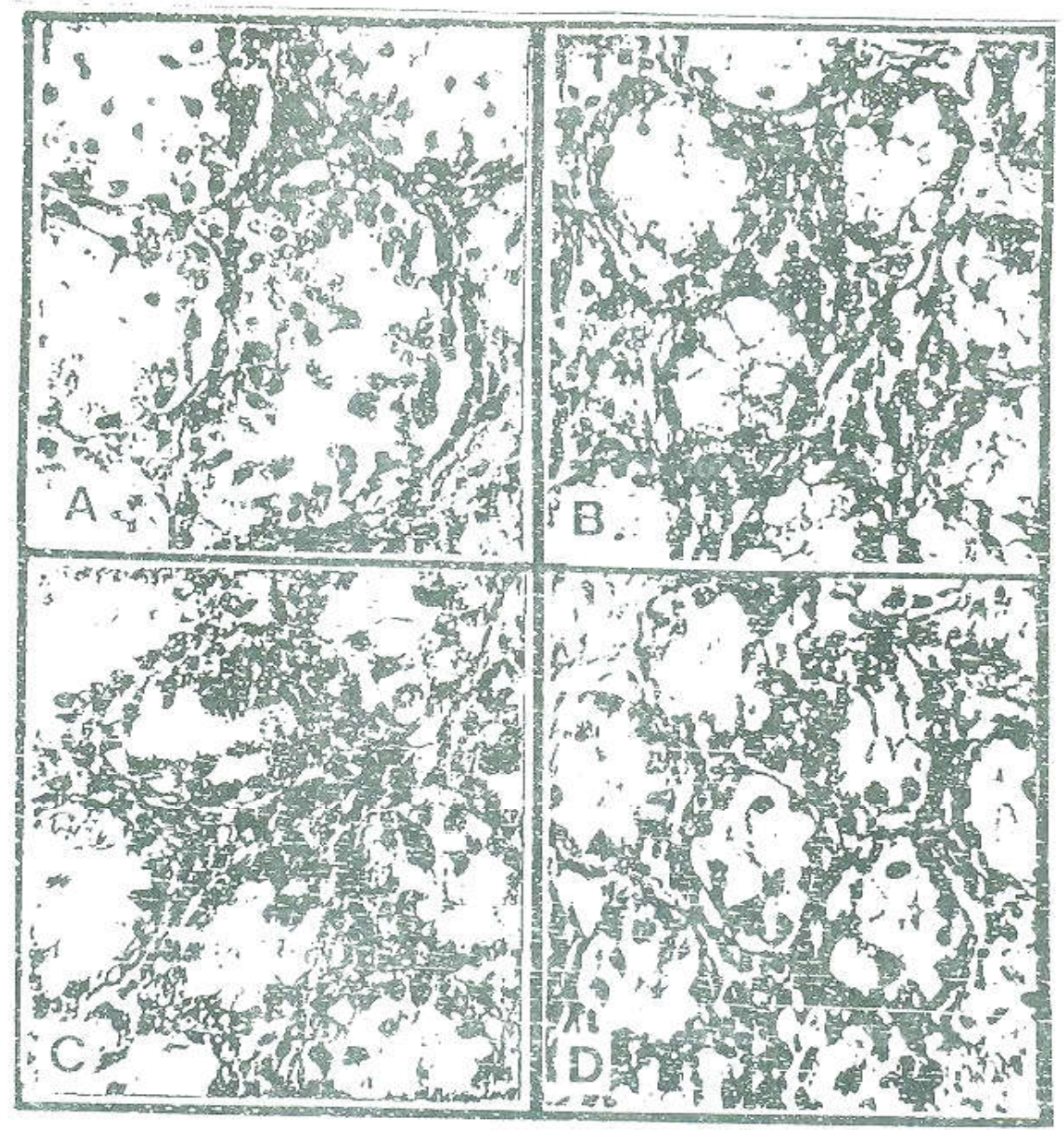

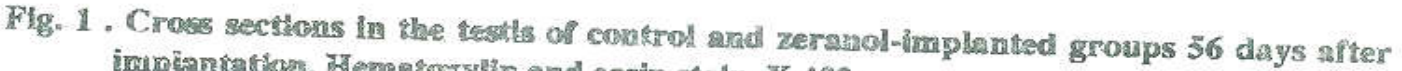

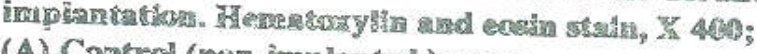

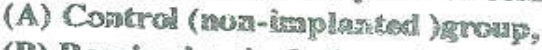

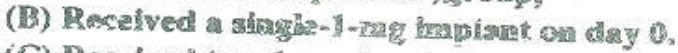

(C) Recofved two l- ling

(D) Recelved a singhe 2-reas- implent om ciay 0

Note that sections of hiphlated groupe are characterined by decreased seminiferous

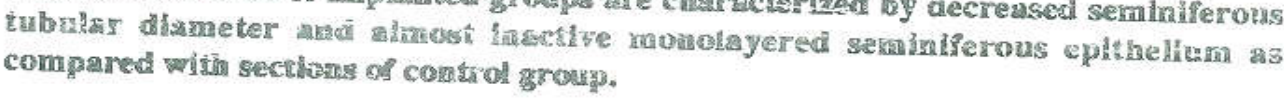




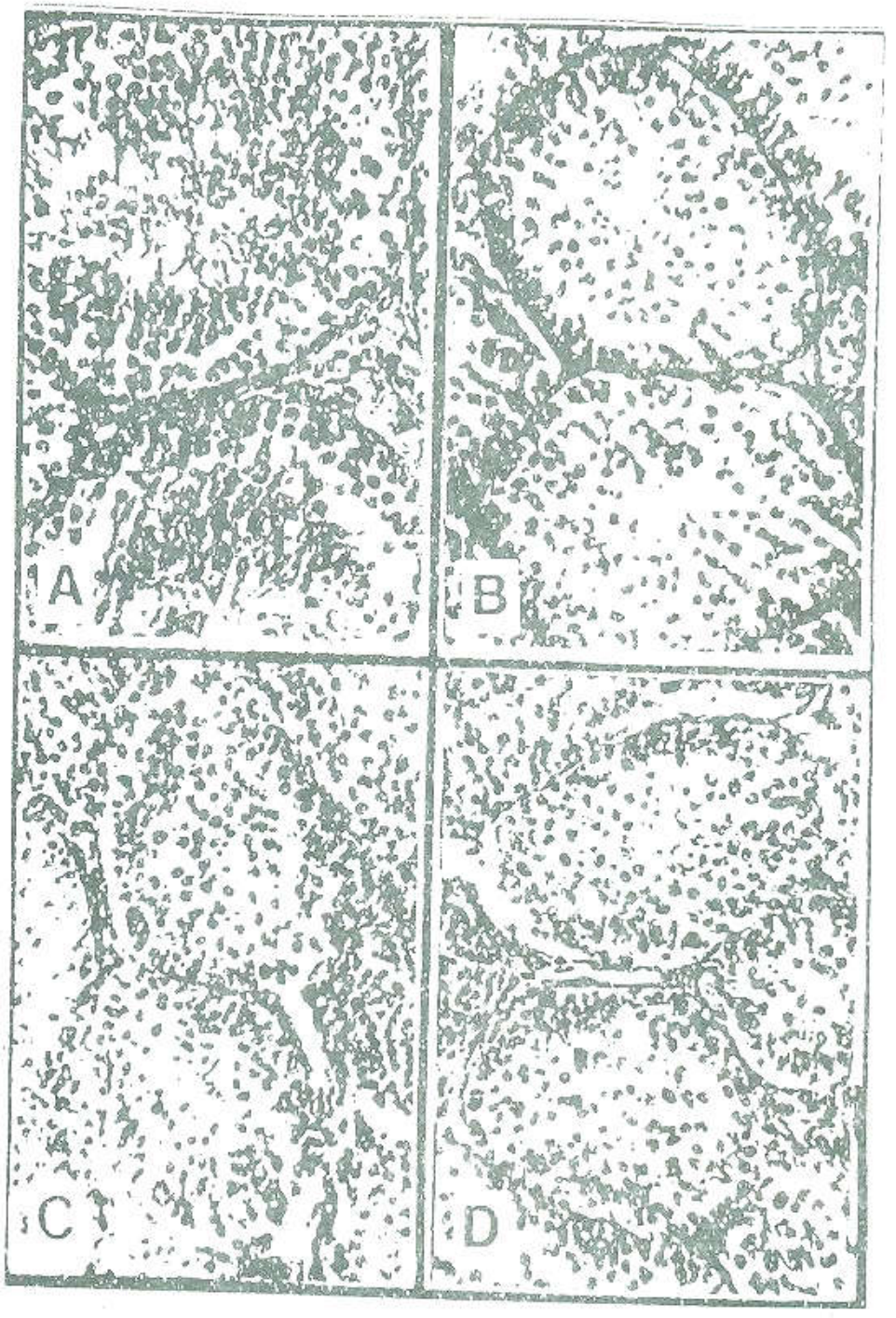

Fig. 2. Croes nectidons fin the testis of coztrol and zermol-implanted groups 112 days after

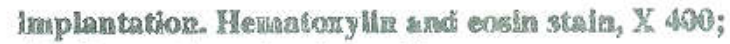

(A) Control (nos-tmplaxted )

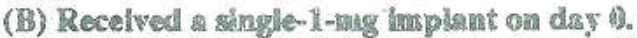

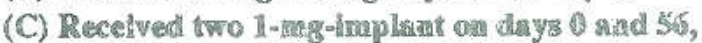

(D) Recelved a slingle 2-rag- traplant on day a .

Note that sectloas of control growp showed fur active seminifercus epithellum.

Spermatogenlc cellbs are suecessively arramged frozn spormatogoufa to spermatozoa. Sectons of impolsmted growps are chargcterized by sansller seminiferous tubular disaneter and abserace of spermitkpizon.

Egypt.J.Anim. Prod ., 28, No.1 (1991) 
Estimates of testicuiar sperm reserves presented in Talle 2 support the nistological findings mentioned above. The average toral testicuiar spem reserve for animals of the zeranol-treatsi groups B, C and D were only about $16 \%, 14 \%$ and $15 \%$ resp. of that for centrol group $\mathrm{A}$. Alruost no difference could be observed due to repeated implantation on disy 56 (group C) or to doubling the cose implanted (group D).

The inhibitory effect of zeranol on testicular growth agd spermatogenesis observed in the present study was reponicd by many workers in catule and shcep íe.g. Wiggins et al., 1976: Corah el al., 1979; Gregory and Ford, 1983; jusiewicz et al., 1985; Godfrey et al., 1989). Several authors reported that zeranol implants remarkably suppressed serum testosterone concentration (Fabry et al., 1993; Staigmiller et al., 1985; Gray et al., 1986; Silcox et al., 1986; Godfrey ef al., 1989). The lower concentrations of testosterone in implanted males suggest that zeranol nay interfere with normal luteinizing hormone (Lii) secretory episodes and likely is recognized as an estrogen by the hypothalamus (Gray $\epsilon t$ al., 1986) Silcox er al. (1980) reported that Leyding cells of zeranol-treated bulls had less smooth endoplasmic roticulura which may be the reason for the lowest iestosterone concentration in the impianted males. This inhibitory effect on concentrations of androgens in the peripheral cinculation in implanted males may explain the absence of resporase in body growth to zeramol obtained in the present study since androgens have been implicaied in causing increased body growth rates in males (Gortsema ế al., 1974).

In conclusion, results of the present study indicate that using zeranol implants for weanling male rabbits in doses of a single i-rig-implanied, two i-mg-implants (56-day interval) or a single $2-r$ g-implart showed ne beneficial cffects on either body weight gaint or efficicacy of feed atilizetion over a pexigd of 16 weels. Morcover, testis of zeranol-impianted animals were tharkediy atrophied, while adrenals showed hypertrophy.

Better results may be obtained if other schedules of implantation are cxamined at different ages.

References

Baker, F.H. and Arthand, V.II. (19\%2) Usa of homones or hornone sctive agenta in production of slaughier bullis. J. Aplim. Sci., 35: 752.

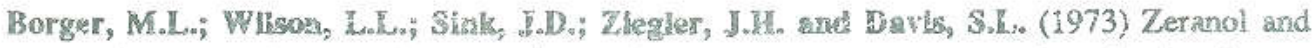
dietary protein level effocts on live performace, carcss merit, certsin endocrine factors end biood metabclite levele of sters. J. Anims. Sci., 35: 706.

Egypt.J.Aram. Prod., 28, No.1 (1991). 
Coralh, L.R., Fink, Lo; Kirecofe, G.H. and McKee, M. (1979) Sexual development and carcass traits of bulls after secuential implanting with zeranol. J. Anim. Sci., 49 (Suppl. 1): 287.

Elsasser, T.H.; Bolk, D.J.; Gredlley, B.D. and Roper, M. (1983) Acute and chronic changes in adenohypophyseal homone secretion in sheep during zeranol administration. Am. J. Vet. Res., 44: 1068 .

Fabry, J.; Resaville, R.; Hallewx, V. and Burny, A. (1983) Plasma testosterone and LH responses to LKRH in double muscled bulls treated with trenbolone acetate and zeranole. J. Anim. Sci., 57: 1138 .

Ford, J.J. and Gregory, K.25. (1983) Effects of late castration and zeranol on feedlot perfomance and carcass charecteristics of bovine males. J. Anim. Sci., $57: 286$.

Godirey, R.W.: Randel, R.D. and Rouquette, Jr., F.M. (1989) Effect of zeranol on sexual development of crossbred buils. J. Anims. Sci., $67: 1751$.

Gortsema, S.R.; Jacohs, J.A.; Ssaser, R.G. Gregory, T.L. and Bull, R.C. (1974) Effects of endogenous testosterone on production and carcass traits in beef cattle. J. Anim. Sci., 39: 680 .

Gray, D.G.;Ümrwh, J.A.; Dikeman, M.E. and Corah, L.R. (1984) Effects of Ralgro implantation periods on inssculinity and carcass traits of young bulls and steers. Kansas Agr. Exp. Sta. Rep. of Prog., 448:14. Karnas State Univ., Manhattan.

Gray, D.G., Uwruh, J.A.; Dheram, M.E. and Stevenson, J.S. (1986) Implanting young bulls with zeranol from birth to four slaughter ages. III. Growth performance and endocrine aspecis. J. Aning. Sci, $63: 747$.

Greathouse, J.R.; Huat, M.C.; Dikeman, M.E., Corah, L.R.; Kastner, C.L. and Krop?, D.H. (1983) Rarlgro-implanted bulls: Performance, Carcass characteristics, longissimus palatalility and carcess electrical stimulation. J. Anim. Sci., 57: 355 .

Gregory, K. K. and Ford, J J. (1983) Effects of late castration, Zeranol of and breed group on growth, fead efficiency and carcess characteristics of late maturing bovine males. $J$. Anim. Sci.p 56: 771 .

Juniewlez, P.E.; Welisw, Iro, T.H. and Johnson, B.K. (1985) Effect of zeranol upon bovine iesticular function Theringenalogy, 23: 565 .

Mirrochu, C.J; Pathre, S.V.; Christemen, C.M. (1977) Zearalenone. In: "Mycotoxins in Human and Aminal Healsh." J.V.Rodricks, C.W.Hessiltine and M.A. Mehlam (eds.) Pathotox publishers Inc., Forest Park, IL. 345.1977 .

Egypt. J . Anim. Prod, 28, No.1 (1991) 
Orgebin-Crist, M.C. (1968) Gonadal and epididymal sperm reserves in the rabbits: Estimation of the daily sperm production. J. Reprod. Fert., $15: 15$.

Perry, T.W.; Staub, M.; Thulwer, D.A. sind Peterson, R.C. (1970) Effect of suhcutaneous implantation of resorcylic acid lactone on performance of growing and finishing beef cattle. $J$. Anim. Sci., 31: 789.

Ralston,A.T. (1978) Effect of zeranol on weaning weight of male calves J Anim.Sci., 47:1203.

Silcox, R.W.;Keeton, J.T. and Johnsom,B.H. (1986) Effects of zeranol and trenbolone acetate on testis function, live weight gain and carcass traits of bulls J Anim.Sci.,63:358.

Snedecor,G.W. and Cachrag, W.G. (1976) "Statistitical Methods" (6th Ed.) The fowa state Univ.Press., Ames., lowa,USA.

Staigniller, R.B.,Bellows,R.A. and Shert, R.E. (1983) Growth and reproductive traits in beef heifers impianted with zeranol.j.Anim Sci., 57:527.

Staigmiller, R.B.;Browtion, R.M.:吕artchner, R.J.snd Whilians, J.H.(1985) Sexual development in beef bulls following zeranol implants. J.Anim Sci., 50:342.

Thomas, O.O and Armitage,J.(1970) Zearalonol for growing fattening steers. Proc.West.Sec.Amer.Soc.Anim.Sci., 21:99.

Thomas, O.O;Armiltage,J. and Sherwoxd,0.(1970) Zearalonol and stilbestrol for suckling cavles.Proc.West.Sec.Aner.Scc.Anim.Sci.29:93.

Wiggins,J.P.; Wllson,L.L.; Rothenbacher, Wh.and Davis, \$.L.(1976) Effects of diethylstibestrol, zeranol and sex on live, blood metabolite, carcass and endecrine characteristics of lambs_J_Anim.Sci., 43:518. 


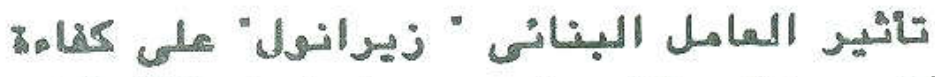

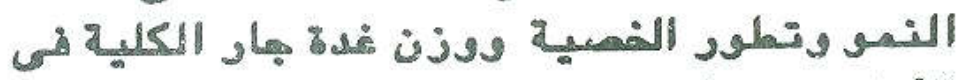

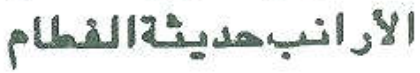

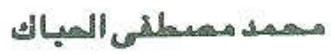

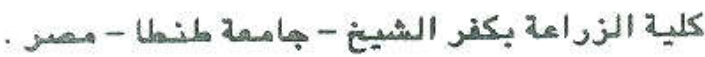

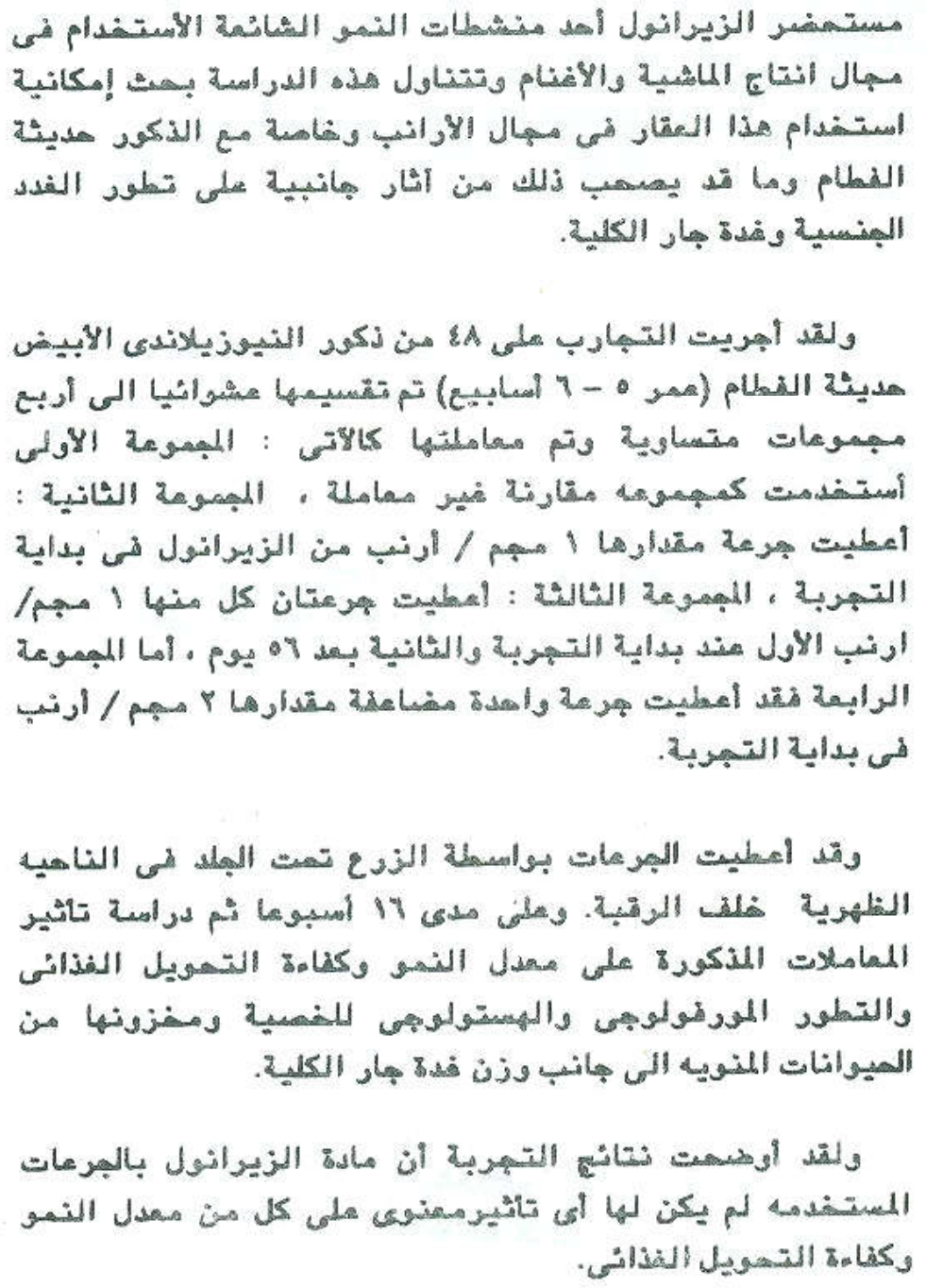

Egypt. J. Anim. Prod., 28, No.1 (1991) 


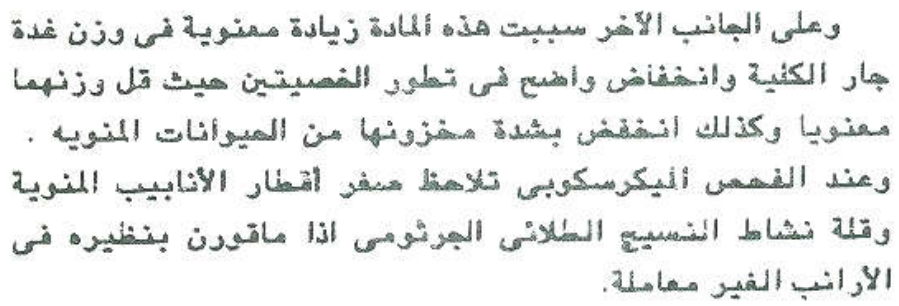

